\title{
Agencies, ministers and civil servants in Britain
}

\author{
Brian W. Hogwood, David Judge and Murray McVicar \\ Department of Government \\ University of Strathclyde \\ Glasgow G1 1XQ \\ United Kingdom \\ e-mail: b.hogwood@strath.ac.uk
}

Paper prepared for presentation to the Workshop on Politicians, Bureaucrats and Institutional Reform at the European Consortium for Political Research Joint Sessions of Workshops 26-31 March 1999, Mannheim, Germany.

The research for this paper was funded by a grant from the British ESRC (L1242451014) for a project 'The Audit of Accountability: Agencies and their Multiple Constituencies' in the Whitehall Programme. All the above 
named authors shave participated in the research reported here, but the drafting of this paper has been the responsibility of the first named author. 


\begin{abstract}
Huge variations exist in the relationships between politicians and agencies in Britain, from very frequent contact in a politicised atmosphere to the complete absence of a direct relationship at all. The nature of the relationship appears to be determined less by agency status as such as by the political sensitivity of particular policy issues. While politicians are not involved in the day-to-day running of most agencies, they have been concerned with operational matters in a small number of agencies. While many agencies have no direct input into policy issues (and there are few directly concerning them), in a limited number of cases the agency is the main source of policy advice because it is the repository of expertise, and in others the agency has the right to be consulted about any policy proposals affecting them, and to make policy proposals. The British Next Steps agency form, because of it relatively informal status, is relatively adaptable to new purposes. Thus, agency status as such has provided little hindrance to the new Labour government. Similarly, while agencies were originally set up and largely operate with a vertical perspective on meeting their own targets, the form is adaptable to cross-organisational targets, though it cannot solve conflicting objectives or policies.
\end{abstract}




\section{Introduction}

This paper assesses the impact of the development of Next Steps agencies in Britain since 1988 on a number of the themes of the workshop. The distinctive features of the British system and these developments are set out to assist comparison. Among the themes covered are:

- Does agencification remove the day-to-day involvement of elected ministers?

- How has the issue of policy advice relating to agency programmes been handled?

- What is the relationship between managers in agencies and other civil servants in the host department and core executive departments?

- Has agencification limited the capacity of the new Labour government to carry out policy change?

- What are the implication of agencification for the debate in Britain about joined up government?

\section{Background: The development of agencies in context}

This brief section is designed to set out the development and characteristics of Next Steps agencies in British government for those who are unfamiliar with the details. It also attempts to set this development in the context of other changes in public bureaucracy in Britain, since the implications of Next Steps agencies, including those for accountability, are often discussed in isolation from the implications of those other developments.

On 18 February 1988, Mrs Thatcher, the then British Prime Minister, announced her acceptance of a report produced by the efficiency unit within the Cabinet Office, Improving Management in Government: The Next Steps (The Ibbs Report, 1988), which, she stated, 'recommended that to the greatest extent practicable the executive functions of government, as distinct from policy advice, should be carried out by units clearly designated within Departments, referred to as "agencies" (House of Commons Debates, 18 February 1988, column 1149).

The data shown in Table 1 would appear to indicate that the agency initiative has been a resounding success, with 77 per cent of UK civil servants now in agencies or 'working on Next Steps lines'. It is worth noting that although the net number of agencies and their share of civil servants continued to grow after 1995, the number of staff in agencies did not rise overall, and actually fell between 1997 and 1998, reflecting civil service reductions overall, and in many agencies, as well as the privatisation of agencies. The process of establishing new agencies is still 
not complete at the end of 1998, despite being supposed to be complete by 1993. The candidates for newly established agencies are largely in the Northern Ireland Civil Service and the Ministry of Defence, neither of which appear to have been the targets of the original initiative. Agencies have now been established sufficiently long that they are routinely subject to organisational succession in the form of privatisations, splittings, and mergers; this makes the process of trying to track the process of agency formation by body count complex, since the totals may contain different sets of organisations.

One important point to stress, since it is sometimes the source of misunderstanding, is that staff of agencies remain civil servants and also part of their department, except for those agencies which were already separate non-ministerial departments. A distinctively British feature is that the establishment of agencies, both in terms of the general principle and individual agencies, does not require any legislative action, even secondary legislation.

Table 1 The development of Next Steps agencies

\begin{tabular}{|c|c|c|c|c|}
\hline \multirow[b]{2}{*}{$\begin{array}{l}\text { Year } \\
\text { (April) }\end{array}$} & \multirow[b]{2}{*}{$\begin{array}{l}\text { Number of } \\
\text { UK agencies }\end{array}$} & \multicolumn{3}{|c|}{ UK civil servants } \\
\hline & & In agencies & $\begin{array}{l}\text { Including } \\
\text { 'Next Steps' } \\
\text { lines }\end{array}$ & $\begin{array}{l}\text { As \% of all } \\
\text { UK civil } \\
\text { servants }\end{array}$ \\
\hline 1989 & 3 & 5,800 & 5,800 & 1 \\
\hline 1990 & 26 & 60,800 & 60,800 & 11 \\
\hline 1991 & 48 & 177,000 & 204,000 & 37 \\
\hline 1992 & 66 & 197,000 & 287,000 & 51 \\
\hline 1993 & 82 & 249,000 & 335,000 & 60 \\
\hline 1994 & 91 & 252,000 & 334,000 & 63 \\
\hline 1995 & 97 & 277,000 & 357,000 & 68 \\
\hline 1996 & 102 & 275,000 & 350,000 & 71 \\
\hline 1997 & 110 & 286,000 & 364,000 & 77 \\
\hline 1998 & 112 & 277,000 & 356,000 & 77 \\
\hline
\end{tabular}


The implication of Mrs Thatcher's February 1998 statement appeared to be that the structure of government was to move from an old pattern of monolithic departments with no clear separation of policy and executive functions, in which ministers were responsible for all activities, however detailed, to a new standard pattern of small policy cores with nearly all executive activities carried out by agencies within departments, and with ministers not responsible for day-to-day operational decisions. The acceptance of these before and after patterns is implicit in the early academic critiques voicing concern about the implications of the Next Steps initiative for ministerial responsibility for the actions of their departments (see e.g. Drewry, 1990).

However, the view that the Next Steps initiative has entailed a move away from a previous standard monolithic pattern to a new simple coreagency pattern can be challenged. A monolithic pattern is a grossly inadequate characterisation of how the functions of central government were delivered prior to 1988, and the pattern which applies as the launch of new agencies nears completion has so many variations that a simple core-agency characterisation is insufficient. There are three main issues here (following Hogwood, 1995):

1. The pre-1988 picture was not one of standard monolithic departments, which were the exception rather than the rule. One-quarter of the civil service were in non-ministerial departments (some of which are now also agencies), and many ministerial departments had distinct organisational units within them. A further quarter of the civil service was in the Ministry of Defence, with its distinctive intertwining of civil service and military staff at all levels.

2. The process of organisational change in British central government since 1988 cannot be adequately characterised as the identification of policy advice cores with all executive functions then being assigned to agencies. The establishment of Next Steps agencies was only one of the many forms utilised by government in undertaking organisational change in the means of policy delivery. Others have included the use of statutory non-departmental public bodies, regulators of privatised industries with the status of non-ministerial departments, and the use made of nominally private or voluntary organisations for policy delivery.

3. The prospective pattern on completion of the Next Steps initiative is not one of policy advice cores with all central government executive actions being performed through Next Steps agencies. Rather, there are immense variations in the extent to which the residual department can be considered to be limited to a policy advice core as implied in Mrs Thatcher's statement, and in the extent to which separately identifiable units engaged in delivery take the form of Next Steps agencies. For example, the 
Department of Social Security has over 84,000 of its 87,000 staff in agencies (96.8 per cent) but sponsors only three non-departmental public bodies with a total staff of 100. By contrast, the Department of Culture, Media and Sport has only one agency, employing 231 out of its 612 staff, but sponsors 37 non-departmental public bodies, with a total staff of 12,400 . The debate about accountability of agencies to ministers often focuses on the bilateral link between an agency and the minister, but clearly the relationship between agencies and ministers is bound to be different in a department with 44 agencies (Defence), compared to a department with only one, which is engaged in a core activity (the Employment Service in the Department for Education and Employment).

\section{The standard Next Steps model}

Executive Agencies are based upon a nominal separation of policy and 'operational matters' within departments. The government accepted the Ibbs Report recommendation that 'agencies should be established to carry out the executive functions of government within a policy and resources framework set by a department' (Ibbs Report 1988, 9). The clear assumption was that:

The main strategic control must lie with the Minister and Permanent Secretary. But once the policy objectives and budgets within the framework are set, the management of the agency should have as much independence as possible in deciding how these objectives are met ... the presumption must be that, provided management is operating within the strategic direction set by ministers, it must be left as free as possible to manage within that framework. (Ibbs Report 1988, 9)

The idea behind Next Steps is, thus, in Peter Kemp's words, 'essentially a most simple concept, in some ways almost naive' (HC 313III 1996, 107). Or as Derek Lewis put it more graphically, the concept of agency status 'is not rocket science, it is very simple basic management principles' (HC 313-III 1996, 94, q. 606). Agencies are simply administrative arrangements within departments, the functions exercised by agencies are vested in the department and not in the agency itself, so that the division of responsibilities between agencies and departments is determined by the Framework Document and not by statute (see HC 313II 1996, 35).

The staff of agencies are still civil servants, working under civil service terms and conditions, financed by public finances and accountable through ministers to Parliament (Kemp in HC 313-III 1996, 107) - with the non-trivial exceptions of military and other civil staff who also work in agencies, an element ignored in confining the agency debate to questions 
of ministerial civil service relations. The delegation of tasks, and the extent of managerial devolution to the chief executive is outlined in the Framework Document. The officially proclaimed expectation is that once authority has been delegated ministers effectively 'withdraw' from operational matters - the daily, routine matters that have no general policy implications (Brazier in HC 313-II, 1996, 11). In this sense there would be a 'depoliticisation' of operational matters, but the extent of depoliticisation is limited in practice by the overarching accountability of ministers to Parliament.

In addition to the initial Framework Document, agencies are subject to a five-year cycle of 'Prior Options' reviews, so called because they include consideration of whether the activity should continue at all, be privatised, or organised in a different way. If the decision is to continue the activity as an agency, a new Framework Document is prepared.

There are also annual corporate plans, some of which are kept confidential to the agency and its department for commercial reasons, and annual reports laid before Parliament. An important annual element is the setting of targets for performance indicators, with the results being published in the consolidated annual Next Steps Review.

So the officially proclaimed model is one of separation of policy and execution, operation within a Framework Document which specifies the roles of minister, main department and agency chief executive, and reporting on annual targets. Within that the chief executive is supposed to have operational autonomy, subject to the important caveat of continuing ministerial responsibility. The remainder of the paper explores the extent to which this model applies in practice.

\section{Ministerial involvement in agencies}

One crucial link in the chain of accountability is that between the minister and the agency. One indicator of such involvement is frequency of meetings between Chief Executive and Secretary of State (see Hogwood, Judge and McVicar, 1998, Appendix 1, final column). The variations are extreme, with 43 meetings in the case of the Prison Service, but no meetings in the case of many agencies. There are also variations in the extent to which agency chief executives may participate in weekly meetings of all senior civil servants in a department with ministers.

There are also structural differences in approach arising from the differing status of agencies. Some agencies, such as Companies House, do not formally report through civil servants in the minister's main department, but direct to the minister. This affords them the same status as other non-ministerial departments, such as the Charities Commission and 
the Office for Standards in Education. Other large agencies report through the Permanent Secretary, while smaller agencies may have as their primary contact either a lower rank civil servant or a departmental board. For the agencies associated with the Ministry of Defence there is a specified chain of command which often involves military officers, and through which agencies, large and small, report.

The handling of replies to parliamentary questions provides another indication of the variability in procedures affecting ministers and agencies (see list in HC 313-I 1996, p.xliii). Tony Wright's researches into whether ministers had amended replies from chief executives revealed 'a sort of pick-and-mix system, some had, some had not, some had large figures, some had small figures' (HC 313-III 1996, p. 160, q 930). What he sought to discover, as 'a basic point about accountability', was 'who owns the answers?'. The response is that at one end of the spectrum there are those agencies where PQs are answered exclusively by the chief executive and which are unseen by ministers prior to finalisation (Northern Ireland); and, at the other end, there are those agencies in which ministers routinely 'approve' the replies of chief executives (Transport). However, the difference in formally stated practice IS among ministerial departments. For most, the standard practice is that the minister may see a copy but would not normally intervene (HC 313-I 1996, p.xliii). There is no evidence of different treatment in practice within a department according to agency characteristics or visibility. There is neither a standard constitutional practice about the role of ministers in relation to chief executives in accounting for operational matters, nor a systematic attempt to structure such relationships on the basis of special characteristics or sensitivities of individual agencies.

The Prison Service scored highest on many indicators of Parliamentary interest (Judge, Hogwood and McVicar, 1997). It also provides an extreme and untypical example of involvement by the minister, with the two forms of interest being clearly related The formally-stated position of the Prison Service is that it is structured so that the principal responsibility for prison policy rests with the Home Office. Prison management is the responsibility of the Director General, the Prisons Board and individual prison managers (Cooper, 1995, p.141). The concept of the division of labour is the inspiration behind entire Next Steps initiative. However, the Home Office has traditionally been closely involved in Prison Service operational matters, contributing to a culture in which Departmental interference has become the norm (Talbot, 1995).

The absence of a Home Office corporate plan to set out strategy means that, in practice, the Director General has the role of attempting to specify prison policy, subject to various political and public pressures. 
The Director General is open to enquiries from Ministers, MPs and Parliamentary Questions. In Learmont's view, this takes up a 'detrimental' amount of time. Indeed, the amount of paperwork throughout the service is judged to have reached 'epidemic proportions' (p.166).

The Prison Services Framework Document specifies the role to be played by the Home Secretary:

The Home Secretary is accountable to Parliament for the Prison Service. The Home Secretary allocates resources to the Prison service and approves its Corporate and Business Plans, including its key targets.

But the Framework Document is vague in the delineation of responsibility:

The Home Secretary will not normally become involved in the day-to-day management of the Prison service but will expect to be consulted by the Director General on the handling of operational matters which could give rise to grave public or Parliamentary concern.

In Talbot's view, this allows the Home Secretary an important formal influence over operational matters as well as policy $(1995,17)$. For example, evidence submitted reveals that the Direct General's answers to MPs questions are cleared with Ministers. Shortly after his dismissal (an example of 'sacrificial' responsibility), Derek Lewis complained in interview:

Agency status was intended to bring greater operational autonomy to the prison service. This clearly has not happened. There are many observers who now consider the Prison Service to have less autonomy than it did pre-Agency status. There has been very close Ministerial involvement in and scrutiny of operational decisions (Newsnight 16/10/95, quoted in Talbot, 1995, 17).

Of course, the Prison Service is politically salient - sensitive and central to the Department. It is a core service, comprising nearly 80 per cent of Home Office staff. It is large in overall governmental terms, both in relation to staffing and finance. However, the evidence presented to the Learmont Inquiry indicate that the organisation suffered from pathological accountability - where management was forced to donate a disproportionate effort to meeting its responsibility to be 'accountable' (Learmont, 1995). Learmont recorded over 1000 pieces of correspondence between the Prison Service and the Home Office during a four month period, October 1994 to January 1995, 137 of which were 'substantive'. The Director General in particular is open to enquiries from Ministers, MPs and Parliamentary Questions. In Learmont's view, this takes up a 
'detrimental' amount of time. Indeed, the amount of paperwork throughout the service is judged to have reached 'epidemic proportions' (p.166). The inquiry concluded that upwards communication had become the 'raison d'être' of Prison Service headquarters and that a more balanced approach was needed. In particular a balance needed to be struck between informing ministers and managing the Service (Recommendation 70).

Apart from the extreme case of the Prisons Service, there is substantial variation in patterns of ministerial involvement. We can distinguish in principle between underlying patterns and those associated with particular issues or events. A string of events and issues may lead to a longer term pattern of contact between agency executives and ministers. For example, the Meat Hygiene Service was different from most agencies in that it was not simply an existing civil service activity separated out into an agency. Problems with its establishment, and subsequently the BSE crisis, e-coli outbreaks in Scotland, and Labour's commitment to a Food Standards Agency, meant a high frequency of contact between the chief executive and ministers at all levels within the department. Other executives might be involved on relevant matters; for example, the finance director had several meetings within one month on issues concerning charging.

For other agencies, including many in the Ministry of Defence, there would be very little ministerial involvement, except when there was a high profile issue like announcing a market test or a workshop closure, where the need to refer the matter to the minister's office would lead to delays.

The key determinant of the extent of ministerial involvement appears to be the political sensitivity of the work of the agency, rather than agency status as such. For some, such as the Prison Service, the involvement is almost constant. For some others, such as the Child Support Agency, it is cyclical, and for others, such as the Meat Hygiene Service, a crisis and an upsurge of political involvement can lead to greater ministerial involvement.

\section{Policy and agencies}

If continuing involvement of ministers in the day-to-day affairs continues for a limited number of agencies, it is worth considering whether the other side of the official Next Steps coin applies: are policy matters solely a matter for the core of ministerial departments? The answer is that while for a large number of relatively technical or support agencies there is little or no policy input by agencies, largely because there are few policy consideration directly relating to them. However, some agencies do have a formal policy role. 
At one extreme there is the Pesticides Safety Directorate, which has as one of its functions defined in its framework agreement to 'develop policy on pesticides and plant protection and advise the Minister accordingly'. This reflects the fact that all the expertise of the department on pesticides is now concentrated in the agency. This raises a broader issue of how ministers and departments are able to evaluate policy advice coming from the body responsible for implementation, particularly in the light of the reductions in the core of some departments.

There is a particular issue concerning non-ministerial departments, that is departments headed by a director or board of officials and reporting to Parliament through the minister, but not through the officials of his main ministerial department. Some of these non-ministerial departments are also agencies. Civil servants in the ministers main department are traditionally reluctant to comment to ministers on matters affecting non-ministerial departments. This can lead to perceived gaps as in the National Audit Office criticisms of the privatisation of HMSO, a non-ministerial department and agency.

A more common form of involving agencies in policy is reflected in the Employment Service framework document:

The Chief Executive may make proposals to the Secretary of State for changes in the policies and programmes operated by the Agency, consulting the Permanent Secretary of the Employment Department Group to ensure that they are consistent with the overall policy objectives of the Group. The Chief Executive is a member of the appropriate senior Employment Department Group committees and in that capacity participates in discussions about its overall policy.

Here the chief executive is very much part of the senior management and policy team of the department (now the Department for Education and Employment).

\section{Managers and managers}

The workshop outline refers to the relationship between politicians and managers in agencies. Our research has shown that for many chief executives the relationship between ministers (even if this is expanded to include the ministers' offices) and chief executives is minimal to nonexistent. This appears to raise interesting questions about accountability. However, our research has also shown that all agencies (and nondepartmental public bodies) are subject to a wide range of forms of scrutiny by civil servants both in the host department and those in the Cabinet Office or Treasury concerned with system-wide issues, to the 
extent that some agencies regarded these pressures as undermining the managerial autonomy the agency model should have given them (see Hogwood, Judge and McVicar, 1998)

A key source of pressure comes in the form of departmental requests for information. It is in this area that we found most of the main complaints about accountability overload. This did not focus on ministerial involvement (indeed, most recognised that agencies must be able to respond to immediate requests for information by ministers). Given the experiences of Derek Lewis and Michael Howard, we might have expected to find more sources of tension, but the following view was typical:

The Minister has to be kept informed of things that may affect him, of questions that may come up in the House ... there is a need to protect the Minister - in a sense to do work for the Minister.

Such a philosophical approach was not extended to the relationship between departments and some (although not all) of our selected organisations. The following provide examples of typical grievances and complaints:

The provision of information is becoming an increasing requirement. The department that has had the largest increase in staff numbers has been the operations department - purely to meet this increase in information need. It's very serious...It's the old story. You provide information and people either disagree with it or ask questions about it and the whole thing snowballs. I've never comes across in life so many bits of paper and the need to supply so much information. You get buried with the damn stuff. My in-tray is full and, each day, I get around 40 e-mails ... you develop a technique and you just have to deal with the most important bits. (Agricultural Next Steps agency concerned with regulation)

I am very much aware that we have targets, and I spend a very large part of my time ensuring that we are actually meeting these targets ... that is a very important part of my job but I'm not able to go and talk to my more junior staff and see how they are getting on. I am not as aware of the progress of individual bits of [the organisation] as I would like because I am saying: 'how's the money doing' and 'are we on track'? (Next Steps agency concerned with research)

A number of officers commented that they had been disappointed with agency status and the lack of autonomy:

My understanding of agency status was that you would have a certain amount of autonomy to get on and run the business. That seems to be less and less ... 
and increasingly they seem to be more prescriptive. We can actually do things much more efficiently if we are allowed to get on and do it but, because everything is so regimented and regulated, it actually makes it more inefficient and time-consuming. The amount of paper work I have to fill in ... (Small Next Steps Agency providing fringe service)

I think it's contrary to what the Next Steps agency process should be all about. I mean, we are monitored by our performance targets, we're audited financially and technically. Next Steps agencies were created to be detached, autonomous, self-standing units who could be monitored from a distance and left to get on it. We are not left to get on with it. There's a lot of interference in terms of form-filling. (Agricultural Next Steps Agency concerned with regulation)

Repetition of requests for information was a particular source of grievance.

A major source of resentment reported to us by our interviewees comes in the form of departmental-wide information-gathering exercises. Pressures apply to small as well as large agencies and sometimes impacts on smaller bodies more directly, as they have to take part in these department-wide surveys and requests for information while having relatively few resources (in terms of staff) to devote:

I think quite a bit of it is unnecessary. I get quite frustrated that we have to fill in our respective part of major departmental reports, or the Next Steps Agency Review. Does anybody read these bloody things? And there's all sorts of really stupid forms we have to fill ... a lot of routine stuff I have always been dubious about the value of. (Agricultural Next Steps Agency concerned with regulation)

Financial accountability also provides examples of information demands on an organisation. Next Steps agencies vary along the whole range of funding, from 100 per cent government funding of their activities to fully covering all their costs from fees or charges. Related to this is the difference in trading terms, with some agencies (such as Welsh Historic Monuments, CADW) being Supply financed and required to pay any income into general government funds, some (such as the Vehicle Certification Agency) are Supply financed but operated on a 'net running costs regime', while others have trading fund status, which enables them to offset expenditure. Some agencies, which are non-ministerial departments in their own right, can bid direct to the Treasury for funding. Traditional models of financial accountability assume only the first type of funding.

The mechanics of financial accountability are, therefore, an important aspect of agency relations with the core department and the 
Treasury. Each agency (and other body) is, through ministers, responsible for its expenditure. In the case of Next Steps agencies, each is required to produce an annual report with audited accounts which are laid before Parliament. Most also produce publicly-available corporate plans (except in agencies where to do so would be commercially detrimental). It is clear from our research that the degree of core-department involvement and interference in financial matters is inconsistent. Some agencies reported little contact with the department on a financial level, beyond basic reporting (which can be conducted on monthly basis as well as quarterly and annually). Others were not so fortunate.

Recognition of financial accounting pressures as 'pathological' were, not unnaturally, more often expressed by finance directors than chief executives. The general pattern was that requests for financial information were a reflection of the general agency relationship with the core department. A few of the bodies we spoke to revealed particular difficulties, related to government accounting techniques and Treasury clawback of 'excessive' income:

To spend to budget, is fine. But to underspend, in some respects raises questions. Although we are an agency, about 30 per cent of our business is commercial. In terms of accountability, this is a key issue. The [department], to be quite blunt about it, have no idea. These guys have worked in the civil service their entire careers, they have a very conventional outlook based on the Vote and they have a simplistic way of adding up numbers and a general misunderstanding of needs of a business. We have to be flexible and adaptive but we also have to meet all the criteria of government accounting ... In terms of accountability, with 30 per cent of our business commercial, I feel that only 70 per cent of the accountability is understood by those who monitor our affairs. They do see things in simple terms. We, as an agency carry quite a substantial EYF (end year flexibility) and we need approval to roll money over to the next financial year. Instead of that being accepted as 'you've generated the money, you have good reasons for needing it the following year' ... each year we have to argue the same case with the Department as to why we have this money. There is no chance of a learning curve with the Department because they keep changing the staff. (A heritage Next Steps agency)

Partly as a response to the accounting requirements of core departments, many agencies and non-agencies also operate extensive models of internal financial accountability within their own organisation. These too can be pathological in their impact: 'we have internal accountability which also takes up a lot of time. I won't say it duplicates but supplements all the other types of recording we have to do' (heritage NDPB). However, as one of the Trading Fund agencies argued: 'unless you're a Trading Fund, you're only playing at it'. 
Problems were reported by a number of bodies which have experienced an overload of government accounting requirements and general scrutinies, such as 'prior options', 'quinquennial reviews', 'market testing'. These were identified as pathological pressures, unrelated to the specific need to be accountable, but still department-enforced. More generally, the multiplicity of volumes of guidance was seen as difficult or impossible to fulfil:

\section{Has agencification limited the capacity of the new Labour government to carry out policy change?}

This section uses number of examples of policies of the new government involving organisational change to explore whether the Next Steps agency form acted as a hindrance to the capacity of the new Labour government to carry out policy change. It might appear that with five-year framework agreements and annual plans and targets there might be expected to be a delay in being able to follow through policy change.

The first example provides evidence that the agency form does not necessarily provide a hindrance. The 'New Deal for the Unemployed' involving training and job placement for (initially young) unemployed was a flagship manifesto policy of the Labour Party, to be funded by a special 'windfall' tax on privatised utilities (details are available at http://www.newdeal.gov.uk/). The Employment Service agency, far from seeking to hinder the introduction of the programme, eagerly and successfully seized the opportunity to try to become the lead player, a role which was confirmed for it A revised operational plan for the Employment service for 1997-98 to take into account the priorities of the new government was published on 30 July 1998 (Employment Service Press Release 04/97). In other words, given the lack of legal status to the annual plans and agreements, they can simply be torn up and new ones issued.

Of course, an agency might be expected to be cooperative over a programme which provides more funding opportunities. The saga of the Food Standards Agency might appear to provide a counter-example, since it has still not been established nor has legislation been introduced. The political background includes the BSE crisis and Labour criticisms of the previous government over this, as well as a fatal outbreak of e-coli food poisoning. The proposed remit covers the concerns of two main departments Health and Agriculture, Fisheries and Food (MAFF) (plus Scottish and Welsh ones) and relates to the activities of a number of existing agencies. However, the main reasons for the delay do not appear 
to be obstruction by existing Next Steps agencies (at least according to our interview at the Meat Hygiene Service). Rather the delays spring from:

(a) the inherent complexity of the subject and the ambiguity of the boundaries of food standards (should it include dietary advice, for example);

(b) the expected turf war between Health and MAFF, the latter having in the past played the lead role on food safety and likely to lose it;

(c) the desire of the Labour government to set up the Food Standards Agency not as a Next Steps Agency but to entrench it as a statutory body with an independent board.

In his budget speech on 17 March 1998 the Chancellor of the Exchequer announced that the Contributions Agency, which collects social security contributions would transfer from the Department of Social Security to the Inland Revenue (details are at http://www.dss.gov.uk/ca/transfer.htm). The fact that primary legislation was involved and that a year was to pass from announcement to implementation might appear to contradict the statement earlier about the lack of legislative basis to agencies and their relative flexibility. The legislation concerned is the Social Security Contributions (Transfer of Functions, etc.) Act 1999 and its purpose is set out in an official Explanatory Note (available at http://www. hmso.gov.uk/acts/en/1999en02.htm).

However, the requirements for legislation have nothing to do with the agency status of the Contributions Agency but stems from:

(a) The fact that the Inland Revenue is a non-ministerial department and therefore (unlike transfers between ministerial departments) there is a need to change of references to 'the Secretary of State' to 'Inland Revenue';

(b) the need for legislation to bring appeals relating to contributions under the Commissioners of Income Tax.

The final example concerns rail regulation. In its manifesto Labour had made clear its wish to change the regulatory framework for rail, which was in the process of being privatised, largely through franchising. In office, the Secretary of State for the Environment, Transport and the regions proposed merging the existing statutory Office of Passenger Rail Franchising (OPRAF) and the Office of the Rail Regulator (ORR) into a single statutory Strategic rail authority. However, he was unable to gain legislative time in the 1998/99 session, and legislation is unlikely to be in place before 2000 .

Overall then Next Steps agency form as such does not hinder policy change brought in by an incoming government, though related legislative requirements unconnected with agency status may cause delays. Where a previous government has not used Next Steps agency form but has 
entrenched the organisational structure in legislation, or where the incoming government itself wishes to entrench a new reorganised body, then greater difficulties and delays may arise.

\section{What are the implication of agencification for the debate in Britain about joined up government?}

Concern has been expressed at both political and civil service levels about the extent to which British government is fragmented and the need for 'holistic' or 'joined up' government. (The term holistic government was developed by Demos think tank, whose former head now works for the Prime Minister.) Civil Servants at the very highest level have expressed concern that agency status and the associated performance targets may have encouraged those working in them to concentrate on the 'vertical' dimension of policy delivery rather than links across organisations (information obtained at talk in December 1998 given under Chatham House rules.) Certainly, the whole focus of framework documents corporate plans and annual targets might seem to channel the concern of agency management into 'minding their own patch', with no apparent responsibility for the implications for other parts of government.

However, the view taken here is that while there are major problems of lack of coordination and conflicting policies, agency form as such makes only a minor contribution to this.

The first point to make is that many agencies have as their remit the supply of services to other parts of government, either according to agreed targets or on a purchasing basis.

Secondly, while most existing targets are indeed concerned with the operations of individual agencies, there is scope for targets relating to cooperation with other agencies. For example, for example, in 1997/98 the Employment Service was given a target of ensuring that $90 \%$ of claims to Job seekers Allowance were passed on to the Benefits Agency within seven days, though this and other targets were discontinued for 1998/99 'to focus ES efforts on key priority areas'. The problem is to define just what areas of coordination can usefully be translated into targets. Narrowly defined targets may by themselves do little to improve general coordination beyond the letter of the targets.

Even before the move of the Contributions Agency to the Inland Revenue in 1999, formal Joint Working arrangements had been set up in 1995, though clearly it was felt desirable to go beyond this.

Finally, the delivery of some programmes already involves agencies in teamwork with a range of other governmental and non-governmental bodies. As mentioned earlier, the Employment Service agency has taken the lead role in the government's New Deal programme, a term which 
itself implies that other organisations are involved. These include local authorities and Training and Enterprise Councils.

Next Steps agencies do have the potential to exacerbate tendencies towards 'picket fence' government. However, they also have the potential to form part of cross-government cooperation through target setting or funding which purchases services or cooperation. Agencies as such are neither a help nor a hindrance to the endemic problems of conflicting policies and objectives. It is worth remembering though that structured conflict can be a way of ensuring that issues are public aired. To take two non-agency bodies with a statutory basis the Office of Water Services (OFWAT), a non-ministerial department, which has a remit to control prices, regularly clashes with the Environment Agency, a nondepartmental public body, which it accuses of wanting to impose excessively costly environmental improvement obligations.

\section{Conclusion}

Making generalisations about the relationships between politicians and agencies in Britain is hampered by the huge variations which exist, from very frequent contact in a politicised atmosphere to the complete absence of a direct relationship at all. The nature of the relationship appears to be determined less by agency status as such as by the political sensitivity of particular policy issues, some the result of policy issues, but others in response to crises or developments. While politicians are not involved in the day-to-day running of most agencies, they have been concerned with operational matters in a small number of agencies, in part because the distinction between policy and operational matters is not the same as the distinction between politics and administration. While many agencies have no direct input into policy issues (and there are few directly concerning them), in a limited number of cases the agency is the main source of policy advice because it is the repository of expertise, and in others the agency has the right to be consulted about any policy proposals affecting them, and to make policy proposals.

The British Next Steps agency form, because of it relatively informal status, is relatively adaptable to new purposes. Thus, agency status as such has provided little hindrance to the new Labour government. Where difficulties have arisen is where the previous government entrenched arrangements in statutory regulator form or where the new Labour government wishes to entrench its own proposals in the form of a statutory body rather than agency reorganisation. Similarly, while agencies were originally set up and largely operate with a vertical perspective on meeting their own targets, the form is adaptable to cross-organisational 
targets, though it cannot solve conflicting objectives or policies. However, considerable caution should be exercised in considering the potential transferability of the British version of agencies (see Hogwood, 1994), both because of the wide variation in British agencies, and because the existence of this form very much reflects distinctive features of British public administration. 


\section{References}

Cooper, P. (1995) Separating policy from operations in the Prison Service: a case study, Public Policy and Administration, 10 (4), pp.4-19.

Drewry, G. (1990) Next Steps: the pace falters, Public Law, 332-9.

HC 313 (1996) Ministerial Accountability and Responsibility, Second Report from the Public Service Committee, Session 1995-96, HMSO, London.

Hogwood, B. W. (1994) A reform beyond compare?: the Next Steps restructuring of British central government, Journal of European Public Policy, 1, 71-94.

Hogwood, B. W. (1995) Whitehall families: core departments and agency forms in Britain, International Review of Administrative Sciences, 61, 511-30.

Hogwood, B. W., D. Judge and M. McVicar (1998) To much of a good thing?: the pathology of accountability, paper prepared for presentation to the Political Studies Association Annual Conference, University of Keele, 7.9 April 1998.

Ibbs Report (1988) Improving Management in Government: The Next Steps: Report to the Prime Minister. London: HMSO.

Judge, D., B. W. Hogwood and M. McVicar (1997) The pondlife of executive agencies: Parliament and informatory accountability, Public Policy and Administration, 12 (2), 95-115.

Learmont Report (Sir John Learmont) (1995) Review of Prison Service Security in England and Wales and the Escape from Parkhurst Prison on 3rd January 1995, Cm 3020. London: HMSO.

Talbot, C. (1995) The Prison Service: a framework of irresponsibility? Public Finance Foundation Review, No. 8, pp.16-19. 